\title{
Long-distance dispersal and recolonization of a fire-destroyed niche by a mite-associated fungus
}

\author{
Janneke Aylward $^{\text {a,c }}$, Léanne L. Dreyer ${ }^{\mathrm{a}, \mathrm{c}}$, Emma T. Steenkamp ${ }^{\mathrm{b}, \mathrm{c}}$, Michael J. \\ Wingfield $^{\text {b c }}$, Francois Roets $^{c, d}$ \\ ${ }^{a}$ Department of Botany and Zoology, Stellenbosch University, Private Bag X1, Matieland 7602, South Africa \\ ${ }^{b}$ Department of Microbiology and Plant Pathology, University of Pretoria, Pretoria 0002, South Africa \\ ${ }^{c}$ Department of Science and Technology (DST)-National Research Foundation (NRF) Centre of Excellence in \\ Tree Health Biotechnology (CTHB), University of Pretoria, Pretoria 0002, South Africa \\ ${ }^{\mathrm{d}}$ Department of Conservation Ecology and Entomology, Stellenbosch University, Private Bag X1, Matieland \\ 7602, South Africa
}

Corresponding author: Janneke Aylward

Department of Botany and Zoology, Stellenbosch University, Private Bag X1, Matieland 7602, South Africa Telephone: +27 21 808-2604

Fax: +27 $21808-2405$

E-mail: janneke@ sun.ac.za

Running title: Recolonization of a fire-destroyed niche by K. proteae

\begin{abstract}
The Fynbos Biome in the Core Cape Subregion of South Africa is prone to recurrent fires that can clear vast areas of vegetation. Between periods of fire, ophiostomatoid fungi colonize the fruiting structures of serotinous Protea species through arthropod-mediated dispersal. Using microsatellite markers, this study considered the process whereby a Protea-associated ophiostomatoid fungus, Knoxdaviesia proteae, recolonizes a burnt area. The genetic diversity, composition and structure of fungal populations from young $P$. repens plants in a recently burnt area were compared to populations from the adjacent, unburnt Protea population. The only difference between $K$. proteae populations from the two areas was found in the number of private alleles, which was significantly higher in the unburnt population. The population structure, although weak, indicated that most $K$. proteae
\end{abstract}


individuals from recently burnt areas originated from the unburnt population. However, individuals from unsampled source populations were also detected. This, together with the lack of isolation-by-distance across the landscape, suggested that long-distance dispersal is

important for K. proteae to recolonize burnt areas. Similarly, the high level of gene flow and low differentiation observed between two distantly separated $K$. proteae populations also supported the existence of long-distance dispersal. The genetic cohesiveness of populations over long distances and the genetic diversity within populations could be attributed to frequent multiple fungal migration events mediated primarily by arthropods but, potentially, also by birds.

Keywords: Fynbos; Knoxdaviesia; ophiostomatoid; recolonize

Abbreviations: CCR, Core Cape Subregion, IBD, Isolation-by-distance; MSN, Minimum Spanning Network

\section{Introduction}

The Fynbos Biome of the Core Cape Subregion (CCR) in South Africa is an unique vegetation type dominated by woody shrubs growing in nutrient-poor soils (Cowling $\&$ Richardson, 1995). The area is characterized by a Mediterranean-type climate with short, wet winters and long, dry summers (Cowling, 1992; Day et al., 1979). Recurrent summer-fires (approximately every 10 to 15 years) often clear vast areas (more than 4000 hectares) of nearly all the above-ground fynbos biomass (Day et al., 1979; Kruger et al., 2000; Southey, 2009) and most plants either re-sprout or recruit from seeds stored in the soil (Keeley, 1995; Wilgen et al., 1992). In the case of serotinous Protea species, mature plants are killed by fire, but their survival is governed by the seeds released from above-ground seed-storage structures (infructescences) that form after flowers mature (Rebelo, 1995). New Protea recruits take $c a$. four years to reach maturity and flower for the first time (Le Maitre \& Midgley, 1992).

Between fires, Protea infructescences are colonized by numerous organisms such as insects (Coetzee \& Giliomee, 1985; Roets et al., 2006b), mites (Theron et al., 2012) and fungi (Lee et al., 2003; 2005), including ophiostomatoid fungi (Roets et al., 2005; 2013). Protea- 
associated ophiostomatoid fungi represent a polyphyletic assemblage (Wingfield et al., 1999) that is characterized by occupation of infructescences and arthropod-mediated dispersal (Roets et al., 2013). The long ostiolar necks of the perithcia and the production of sticky spores make these fungi ideally suited for dispersal by arthropods rather than air currents (Cassar \& Blackwell, 1996). Interestingly, these apparently native ophiostomatoid fungi are not associated with disease symptoms and they have no known adverse effects on growth or reproduction on their hosts (Marais, 1996; Roets et al., 2013).

Knoxdaviesia proteae was the first Protea-associated ophiostomatoid fungus to be discovered (Wingfield et al., 1988). It was isolated from the infructescences of the common sugarbush, Protea repens, an indigenous fynbos species that is the only known host of this fungus (Roets et al., 2009b). Since the discovery of $K$. proteae, 11 additional ophiostomatoid fungi associated with serotinous Protea species have been identified, bringing the current total of species known in this niche to 12 (De Beer et al., 2013). This extraordinary Proteaophiostomatoid fungus association is not restricted to the CCR, but has also been noted in other areas of South Africa and in Zambia (Crous et al., 2012; Marais \& Wingfield, 2001; Roets et al., 2010; 2013).

Like many organisms capable of colonizing Protea infructescences, the Protea-associated ophiostomatoid fungi seem to be specialists of this niche and have not been recorded from any other habitat, including other parts of Protea plants, soil and leaf and twig litter (Lee et al., 2005; Marincowitz et al., 2008). Therefore, recolonization of post-fire, newly formed infructescences by these organisms can take place only via dispersal from unburnt areas. This form of dispersal is more easily achieved for winged-groups like insects, than for the mites and ophiostomatoid fungi. However, many of the mites from this niche are phoretic on beetles that pollinate Protea species (Roets et al., 2009a). Using these Protea-specialist beetles as vectors, mites could easily recolonize infructescences, presumably over long distances. Some of these phoretic mites also have mutualistic associations with the Proteaassociated ophiostomatoid fungi and a few even have specialized spore carrying structures for the fungi on which they feed (Roets et al., 2007). While mites appear to be primarily responsible for spore capture and dispersal on a single $P$. repens plant, beetles carry mites to facilitate long-distance dispersal (Aylward et al., 2014b; Roets et al., 2009a).

Previous research has shown that gene flow facilitated by mites and beetles is sufficient to maintain a panmictic $K$. proteae population in a $P$. repens stand covering approximately three square kilometres (Aylward et al., 2014b). Gene flow between fungi in these plants thus 
exceeds genetic drift, preventing the fungal population from becoming structured based on individual Protea plants. The role of beetles in facilitating between-plant dispersal of mites and the ophiostomatoid fungi they carry, therefore, seems to dominate K. proteae movement within a $P$. repens stand.

Flight mill studies on bark beetles have shown that most beetles achieve at least an hour of uninterrupted flight (Atkins, 1961; Forsse \& Solbreck, 1985) and can reach a speed of two metres/second in still air (Byers, 1996). Mark-recapture studies with the southern pine beetle, Dendroctonus frontalis Zimm., showed that a third of the released individuals dispersed more than one kilometre, leading the authors to conclude that "beetles are capable of dispersing quite far" (Turchin \& Thoeny, 1993). These results suggest that the dispersal kernel (probability distribution) of beetles is typically a fat-tailed one in which long-distance dispersal events are more common (Klein et al., 2006). The geographic distance over which the Protea-beetle vectors are capable of supplying sufficient $K$. proteae migrants to maintain panmixia therefore becomes intriguing.

Recolonization of large areas of burnt fynbos by ophiostomatoid fungi presents unique opportunities to study the dispersal patterns of these Protea-associated fungi. Fire essentially creates a clean slate so that the origin of fungal inoculants in young Protea hosts may be established. Most likely, fungal inoculants enter young plants via short- to medium-distance dispersal from neighbouring Protea plants that escaped the fire. In this case, burnt areas will have ophiostomatoid populations that represent a subset of the ophiostomatoid fungi in neighbouring unburnt areas. Young Protea plants closest to the source populations may also receive more inoculants than plants further away, producing patterns of isolation-by-distance (IBD). Beetles may, however, be able to facilitate sufficient between-plant dispersal that such patterns do not appear. Additionally, beetles may have the ability to transport ophiostomatoid fungi from more distant source populations into the recently burnt areas (Roets et al., 2009a), adding greater genetic diversity and potentially novel genetic information to the population. In this study, we used microsatellite markers specific to K. proteae (Aylward et al., 2014a) to compare fungal isolates sampled from a recently burnt fynbos area to isolates from neighbouring unburnt areas. The aim was to establish whether adjacent, mature $K$. proteae populations act as the source of inoculants for new $P$. repens stands and whether infructescences can be colonized over long distances, in the first year of flowering. In addition, we compared genotypic variation within this population to a $K$. proteae population previously genotyped with the same microsatellite markers (Aylward et al., 2014b) to 
determine the genetic relatedness between two distantly separated populations. In doing so, the role of long-distance dispersal in maintaining $K$. proteae populations could be verified.

\section{Materials and Methods}

\subsection{Fungal sampling}

Sampling of $P$. repens infructescences was conducted along a three kilometre $(\mathrm{km})$ stretch of land in the Franschoek Mountains, Western Cape Province, South Africa (-33.90442; 19.156683). The vegetation in this area burnt in $2008 / 2009$ and the new P. repens plants flowered for the first time when infructescences were collected in January 2013. Knoxdaviesia proteae individuals isolated from these first-flowering-season infructescences could therefore, not have originated from older infructescences on the plant but had to be a result of between-plant dispersal. Patches of fynbos containing mature ( $c a$. 15-17 year old) $P$. repens plants allowed for sampling of infructescences that presumably contained source populations of $K$. proteae for the recently burnt areas (Fig 1).

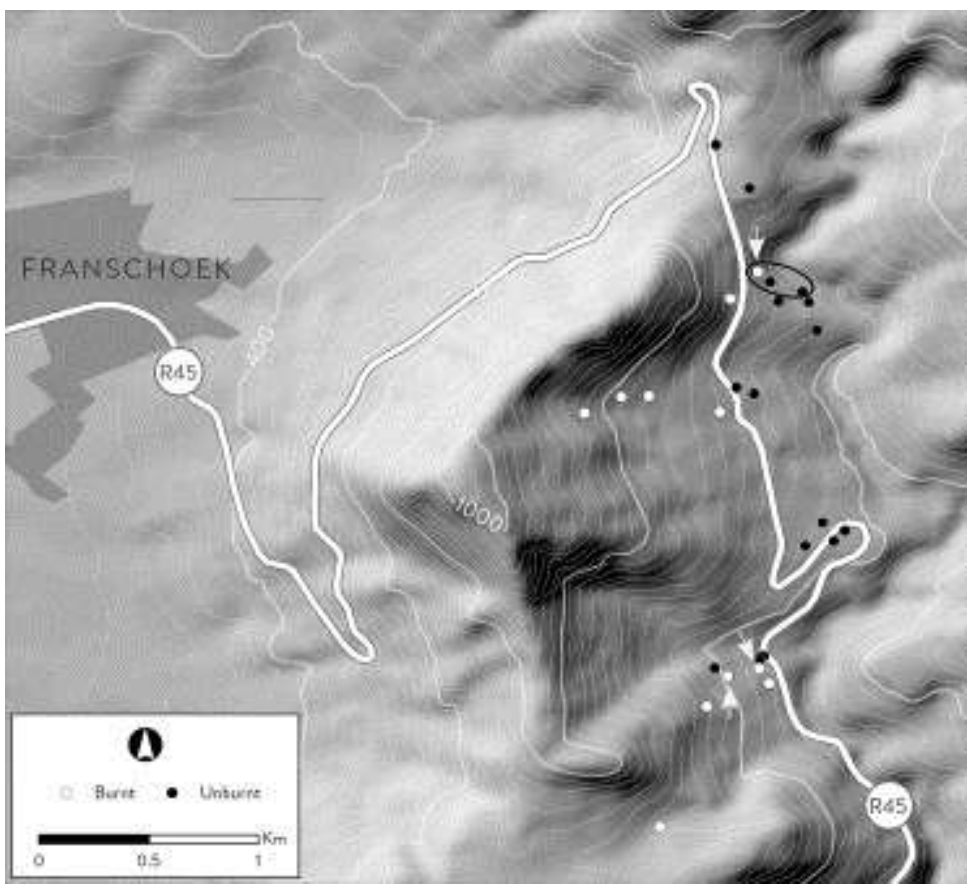

Fig 1 : Franschoek sampling site. Dots represent the midpoints of sampling plots in unburnt (black) and recently burnt (white) areas. Downward arrows indicate plots containing the two individuals with identical genotypes. The upward arrow indicates the plot where the nine individuals that cluster separately to the rest of the population were collected. The three unburnt plots that showed weak, but significant isolation-by-distance with the recently burnt plots are circled (the first unburnt plot is hidden behind the recently burnt white plot). 
Thirty sampling plots were selected depending on availability (11 in the recently burnt and 19 in the unburnt areas), with those in the recently burnt areas chosen at increasing distances from the unburnt areas (Fig 1). A total of $20 \mathrm{ca} .6$ month-old infructescences were sampled from various $P$. repens trees in a 10 metre radius around the midpoint of each sampling plot. Fungal isolations were performed (Roets et al., 2006a) on Malt Extract Agar (MEA; Merck, Wadeville, South Africa) supplemented with 0.04 g/L Streptomycin Sulfate Salt (SigmaAldrich, Steinham, Germany). Individual Knoxdaviesia isolates were obtained by subculturing hyphal tips from Water Agar (15 g agar/L) onto MEA. DNA extraction and species identity verification via the internal transcribed spacer (ITS) region of the rDNA followed previously described methods (Aylward et al., 2014a). In infructescences where K. proteae ascomata were present, at least ten isolations were attempted, but only one K. proteae isolate was maintained to prevent re-sampling of the same individual.

\subsection{Genetic diversity of the $K$. proteae population and origin of isolates in recently burnt areas}

All $K$. proteae individuals were genotyped with 12 microsatellite markers (Aylward et al., 2014a) in three multiplex reactions developed previously (Aylward et al., 2014b). The genetic diversity of the sampled isolates was described by using GENALEx 6.501 (Peakall \& Smouse, 2006; 2012) to compute the effective number of alleles $\left(\mathrm{N}_{\mathrm{e}}\right)($ Kimura \& Crow, 1964), number of private alleles $\left(\mathrm{N}_{\mathrm{p}}\right)$, number of multilocus genotypes and Nei's unbiased estimate of expected heterozygosity $\left(\mathrm{H}_{\mathrm{E}}\right)(\mathrm{Nei}, 1978)$. The latter is the conventional measure of genetic diversity and describes the probability that two randomly sampled alleles will be different. Using R 3.0.2 (R Core Team, 2014), Shapiro-Wilk tests of normality were performed on the data after which Mann-Whitney U tests (W statistic) were used to compare the diversity indices between $K$. proteae populations from the recently burnt and unburnt areas. Genotypic diversity $(\mathrm{G})$ and the maximum percentage of this diversity $(\hat{\mathrm{G}})$ was calculated according to Stoddart \& Taylor (1988) and McDonald (1994), respectively. The evenness index $\left(\mathrm{E}_{5}\right)$ recommended by Grünwald et al. (2003) was calculated with POPPR, a package implemented in R (Kamvar et al., 2013; R Core Team, 2014).

In order to assess population differentiation, isolates from recently burnt and unburnt plots, respectively, were grouped together. The diversity within $\left(\Delta_{\mathrm{S}} / \Delta_{\mathrm{T}}\right)$ and between $\left(\Delta_{\mathrm{ST}}\right)$ subpopulations, the relative population differentiation (D) and Jost's haploid estimate of D 
$\left(\mathrm{D}_{\text {est(hap) }}\right)\left(\right.$ Jost, 2008) were determined with SMOGD 1.2.5 (Crawford, 2010). $\mathrm{D}_{\text {est }}$ is calculated from population estimates that incorporate sample size and ploidy, where a diploid genome is assumed. The estimate was modified to suit haploid data by substituting $2 \mathrm{~N}$ for $1 \mathrm{~N}$ in the Nei \& Chesser (1983) formulas. Theta, a conventional measure of population differentiation analogous to $\mathrm{F}_{\mathrm{ST}}$, was calculated using MulTILOCUS 1.3b (Agapow \& Burt, 2001). -

The premise that recolonization through short- to medium-distance dispersal may produce an IBD effect was investigated with the IsOlation By DistanCE WEB SERVICE 3.23 (Jensen $e t$ al., 2005). A non-parametric Mantel test with 1000 permutations was used to consider whether genetic and logarithmic geographic distances (Rousset, 1997) are correlated and the slope on the graph was determined through reduced major axis (RMA) regression analysis. All sampling plots where fungal isolates were obtained were considered as separate geographic locations and geographic and genetic distances were calculated between them. Geographic distances were calculated from the latitudinal and longitudinal coordinates in GeOgRAPHic Distance MAtrix Generator 1.2.3 (Ersts, 2014). Two genetic distances were used independently - Goldstein's $\delta \mu^{2}$ genetic distance for microsatellites (Goldstein et al., 1995), calculated using MSA 4.05 (Dieringer \& Schlötterer, 2003), and Nei’s unbiased standard genetic distance, uD, (Nei, 1978), calculated in PoPGENE 1.32 (Yeh et al., 1999). Both distances were included, since they follow different mutation models that represent opposite extremes (Chakraborty \& Jin, 1992), the Stepwise Mutation Model (SMM) and Infinite Alleles Model (IAM), respectively. The SMM could be inordinately conservative, especially with regards to the di-nucleotide locus KX1, which can often evolve by multi-step changes (Shriver et al., 1993), and the IAM would therefore provide a useful comparison. In contrast, Nei's distance is likely to be too liberal in its estimation, because it does not consider allele size (Nei, 1978).

To determine whether fungal dispersal from unburnt to recently burnt areas drives IBD, the test was repeated by comparing each sampling plot in the unburnt area individually with each of the plots in the recently burnt areas (therefore ignoring distance measures between unburnt plots). IBD was further investigated by measuring whether the distance from the nearest unburnt area influenced the number of $K$. proteae isolates obtained from recently burnt sampling plots by calculating Pearson's product-moment correlation in R 3.0.2 (R Core Team, 2014).

Population structure was investigated with STRUCTURE 2.3.4 (Falush et al., 2003, 2007; Hubisz et al., 2009; Pritchard et al., 2000). Runs were conducted with an admixture model 
using correlated allele frequencies, 500000 burn-in and 750000 Markov Chain Monte Carlo repetitions. The number of clusters $(K)$ in the population was determined based on 10 independent runs for each $K$ ranging from one to 10 . This process was repeated using the two areas (unburnt and recently burnt) as presumed populations of origin (LOCPRIOR model). STRUCTURE HARVESTER (http://taylor0.biology.ucla.edu/structureHarvester/) (Earl \& von Holdt, 2012) was used to determine the optimal number of clusters in the population by computing $\mathrm{L}(K)$ (the mean log-likelihood of $K)$ and $\Delta K$ (Evanno et al., 2005). The optimal alignment of the 10 independent replicates was found with CLUMPP 1.1 (Jakobsson \& Rosenberg, 2007) and graphical editing of the $Q$-matrix histogram was performed with DISTRUCT 1.1 (Rosenberg, 2004).

Relationships between isolates were also investigated by computing a minimum spanning network (MSN) between microsatellite genotypes based on pairwise genetic distances calculated by the molecular variance parsimony technique in ARLEQUIN 3.5.1.3 (Excoffier \& Lischer, 2010). The MSN, displaying all possible connections, was constructed in HAPSTAR 0.7 (Teacher \& Griffiths, 2011). The reproductive strategy of the $K$. proteae population in Franschoek was investigated by calculating the linkage disequilibrium index, $\overline{\mathrm{r}}_{\mathrm{d}}$ (Brown et al., 1980), in Multilocus 1.3b (Agapow \& Burt, 2001), where random recombination $\left(\overline{\mathrm{r}}_{\mathrm{d}}=\right.$ 0 ) is the null hypothesis. To test significance, the observed value of $\bar{r}_{d}$ was compared to the values calculated for 1000 random datasets. Previous studies have shown that these 12 microsatellite loci are not in linkage disequilibrium (Aylward et al., 2014a; 2014b).

\subsection{Comparisons of genetic diversity and investigation of dispersal between two distantly separated $K$. proteae populations}

The Franschoek population data were compared to genotypic data from a previous study on the genetic diversity of a $K$. proteae population in Gouritz, Western Cape Province, South Africa (Aylward et al., 2014b). These two K. proteae populations are separated by approximately $240 \mathrm{~km}$ and mountainous terrain. Considering all $K$. proteae isolates from both populations, population differentiation and structure was analysed following the methods described above. The respective populations were used as sampling locations in the LOCPRIOR model applied in STRUCTURE. Population recombination was also tested by calculating $\overline{\mathrm{r}}_{\mathrm{d}}$ across all isolates in both populations as explained above. Although the inclusion of $K$. proteae individuals from two different populations would bias the linkage disequilibrium test 
towards non-random recombination (Taylor et al., 1999), failure to detect non-random recombination would suggest that outcrossing is taking place between the two populations.

Table 1: Genetic diversity of the Franschoek Mountain Knoxdaviesia proteae population across 12 microsatellite loci.

\begin{tabular}{|c|c|c|c|c|}
\hline Locus & $\mathbf{N}_{\mathrm{a}^{\mathrm{a}}}$ & Null alleles (\%) & $\mathbf{N}_{\mathrm{e}^{\mathrm{b}}}^{\mathbf{b}}$ & $\mathbf{H}_{\mathrm{E}}{ }^{\mathrm{c}}$ \\
\hline KX1 & 25 & 0.94 & 16.53 & 0.95 \\
\hline KX2 & 21 & 2.83 & 8.88 & 0.90 \\
\hline KX3 & 10 & 0.94 & 3.29 & 0.70 \\
\hline KX4 & 27 & 0 & 6.79 & 0.86 \\
\hline KX5 & 7 & 2.83 & 3.45 & 0.72 \\
\hline KX6 & 8 & 29.25 & 3.14 & 0.69 \\
\hline KX7 & 6 & 0.94 & 2.01 & 0.51 \\
\hline KX8 & 9 & 0 & 4.95 & 0.81 \\
\hline KX9 & 16 & 19.81 & 4.28 & 0.78 \\
\hline KX10 & 11 & 4.72 & 4.56 & 0.79 \\
\hline KX11 & 12 & 2.83 & 4.68 & 0.79 \\
\hline KX12 & 8 & 0 & 4.64 & 0.79 \\
\hline Mean $\pm \mathrm{SEM}^{\mathrm{d}}$ & $13.33 \pm 2.09$ & $5.42 \pm 2.67$ & $5.60 \pm 1$ & $20.77 \pm 0.03$ \\
\hline Excluding KX6 & $13.6 \pm 2.45$ & $1.60 \pm 0.51$ & $5.98 \pm 1$ & $20.78 \pm 0.04$ \\
\hline \multicolumn{5}{|c|}{ a $N_{a}=$ Number of alleles. } \\
\hline \multicolumn{5}{|c|}{$\mathrm{b} \mathrm{N}_{\mathrm{e}}=\underline{\text { Kimura \& Crow's (1964) }}$ number of effective alleles; $N e=1 / 1-h$} \\
\hline
\end{tabular}




\section{Results}

\subsection{Genetic diversity and recolonization of recently burnt areas}

A total of $106 \mathrm{~K}$. proteae individuals were isolated from $16 / 19$ of the unburnt and $7 / 11$ of the recently burnt sampling plots (Table S1). Infructescences from the remaining sampling plots were not colonized by $K$. proteae or could not be used for isolation due to insect damage or a high level of contamination by other micro-organisms. During microsatellite amplification, between zero and $4.7 \%$ null alleles were detected in 10 of the loci. However, similar to the previous $K$. proteae population study (Aylward et al., 2014b), loci KX6 and KX9 displayed exceptionally high null allele percentages (29\% and 20\%, respectively) and were excluded from further analyses. The null alleles in the remaining loci were treated as missing data in analyses.

A high genetic diversity was observed in the Franschoek K. proteae population (Table 1). The exclusion of two loci did not significantly impact the diversity indices and a plot of the number of loci against diversity (calculated in MULTILOCUS) showed 10 loci to be adequate for describing the diversity (data not shown). Of the 106 isolates, 104 had unique genotypes. Two identical genotypes were encountered in different sampling locations $1.8 \mathrm{~km}$ apart; both in recently burnt sampling plots (Fig 1). Stoddart \& Taylor's (1988) genotypic diversity (G) was 104.04 , which corresponds to $98.15 \%$ of the maximum diversity $(\hat{\mathrm{G}})$. The genotypic evenness $\left(\mathrm{E}_{5}\right)$ was 0.994 , identical to the $\mathrm{E}_{5}$ value of a previous $K$. proteae population (Aylward et al., 2014b).

Comparison of the measures of allele diversity between fungal individuals from the unburnt and recently burnt areas revealed a significant difference $\left(\mathrm{W}=96 ; \mathrm{P}=4.7^{-4}\right)$ in the number of private alleles, with the population from unburnt areas having more private alleles (Fig 2A). Although not significant $(\mathrm{W}=74 ; \mathrm{P}=0.07)$, the number of total alleles was also higher in the unburnt area. The expected heterozygosity and effective number of alleles were similar between the two groups. Population differentiation statistics could not detect differentiation between $K$. proteae individuals from the unburnt and recently burnt areas (Table 2) and the effective number of sub-populations $\left(\Delta_{\mathrm{ST}}\right)$ was one, accounting for $99 \%$ of the total diversity $\left(\Delta_{\mathrm{S}} / \Delta_{\mathrm{T}}\right)$

In the first test for IBD, the Mantel test detected a weak correlation using both $\delta \mu^{2}\left(\mathrm{r}^{2}=7.02^{-}\right.$ $\left.{ }^{3}\right)$ and $\mathrm{uD}\left(\mathrm{r}^{2}=0.03\right)$, but only the $\mathrm{uD}$ correlation was significantly positive $(\mathrm{P}=0.02$; Fig 3$)$. Under the IAM, a very weak IBD effect could therefore have been present across this three 


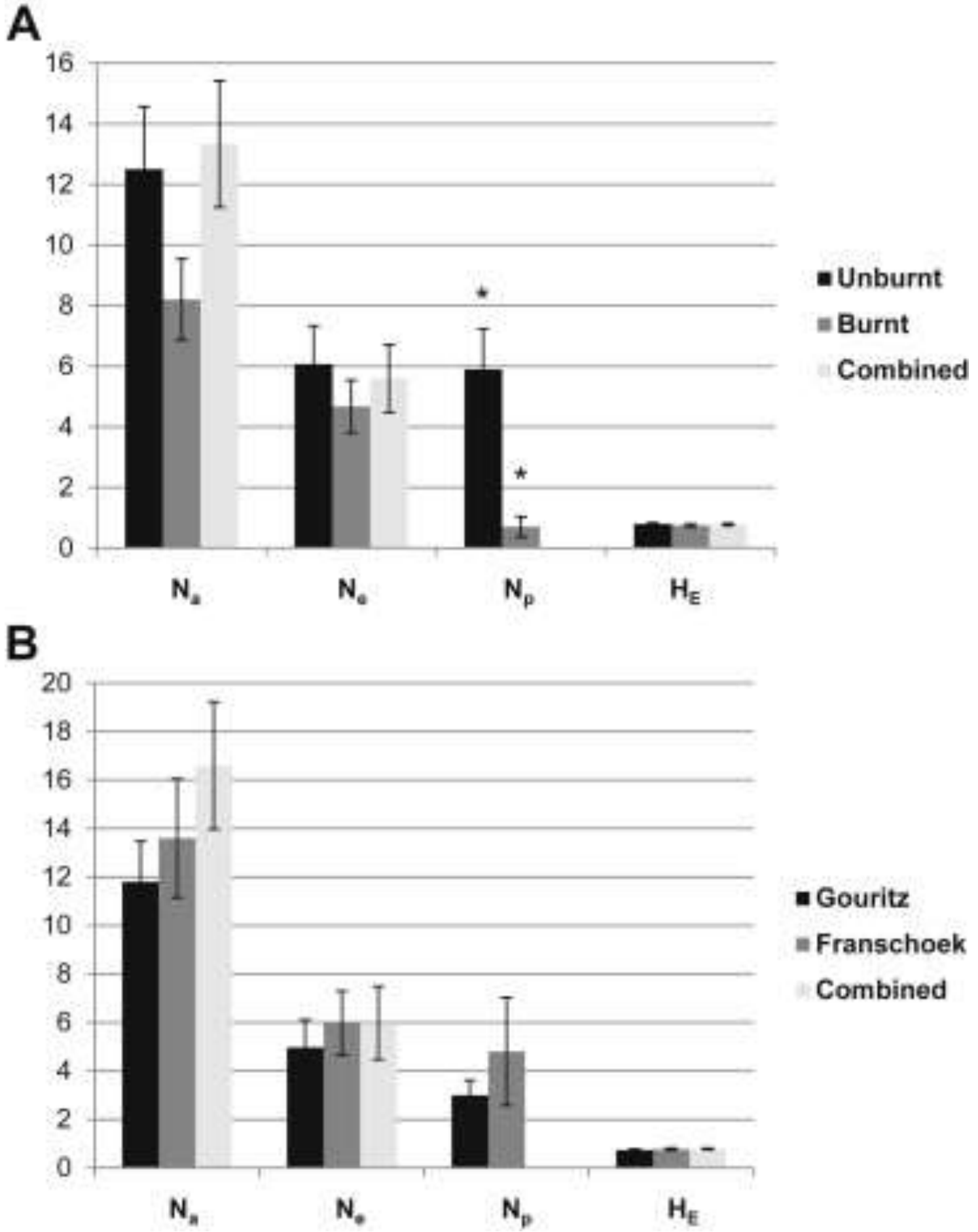

Fig 2 : Comparison between the diversity indices of Knoxdaviesia proteae from the recently burnt and unburnt areas in Franschoek (A) and between the Gouritz and Franschoek populations (B). The mean number of alleles $\left(\mathrm{N}_{\mathrm{a}}\right)$, effective alleles $\left(\mathrm{N}_{\mathrm{e}}\right)$, private alleles $\left(\mathrm{N}_{\mathrm{p}}\right)$ and the unbiased expected heterozygosity $\left(\mathrm{H}_{\mathrm{E}}\right)$ is shown. Error bars represent the standard error of the mean. The only statistically significant difference $(*)$ was observed for $\mathrm{N}_{\mathrm{p}}$ between the burnt and unburnt areas. 
Table 2 : Population differentiation between the $K$. proteae individuals from unburnt and recently burnt sampling plots in Franschoek and between the two distantly separated populations.

\section{Franschoek unburnt vs. burnt Gouritz vs. Franschoek}

$\begin{array}{lll}\tilde{\mathrm{N}}^{\underline{\mathrm{a}}} & 45.45 & 98.51 \\ \Delta_{\mathrm{ST}^{\underline{\underline{b}}}} & 1.01 \pm 0.00 & 1.02 \pm 0.01 \\ \Delta_{\mathrm{S}} / \Delta_{\mathrm{T}^{\mathrm{c}}} & 0.99 \pm 0.00 & 0.98 \pm 0.01 \\ \mathrm{D}^{\mathrm{d}} \quad 0.03 \pm 0.00 & 0.04 \pm 0.01 \\ \mathrm{D}_{\text {est (hap) }}{ }^{\mathrm{e}} 0 & 0.01 \pm 0.01 \\ \theta^{\mathrm{f}} & 0.01 & 0.042^{* *}\end{array}$

$* * \mathrm{P}<0.001$ after 1000 randomizations.

a $\tilde{\mathrm{N}}=$ Harmonic mean of the sample sizes.

b $\Delta_{\mathrm{ST}}=$ Diversity between subpopulations, or the effective number of subpopulations.

c $\Delta_{\mathrm{S}} / \Delta_{\mathrm{T}}=$ Proportion of diversity in a subpopulation.

$\mathrm{d} \mathrm{D}=$ Actual (relative) differentiation.

e $\mathrm{D}_{\text {est(hap) }}=$ The haploid estimate of $\mathrm{D}$;

$D_{\text {est (hap) }}=\left[\left(\mathrm{H}_{\mathrm{T}_{-} \text {est(hap) }}-\mathrm{H}_{\mathrm{S}_{-} \text {est (hap) }}\right) /\left(1-\mathrm{H}_{\mathrm{S}_{-} \text {est (hap) }}\right)\right][\mathrm{n} /(\mathrm{n}-1)] \operatorname{Dest}(\mathrm{hap})=\left[(\mathrm{HT}\right.$ _est(hap $)-\mathrm{HS} \_$est $($ha p))/(1-HS_est(hap))][n/(n-1)].

f $\theta=$ Conventional measure of relative differentiation; $\theta=Q-q / 1-q$.

$\mathrm{km}$ stretch of landscape. All but three Mantel tests, conducted between individual unburnt plots and recently burnt plots, indicated that the IBD is not a result of the recolonization of burnt areas. These three tests were conducted under the IAM and suggested weak $\left(r^{2}<0.2\right)$, but significant IBD between the burnt plots and unburnt plots 3, 5 and 7 (Table S2). These three plots represent the northernmost unburnt plots from which fungal isolations were successful (Fig 1). The distance of recently burnt from unburnt sampling plots did not significantly influence the number of $K$. proteae isolates obtained in this study $\left(r^{2}=0.26 ; t=\right.$ -1.7949; $\mathrm{df}=9 ; \mathrm{P}=0.053$; Fig S1). A Pearson's Chi-squared test performed in R 3.0.2 ( $\mathrm{R}$ Core Team, 2014) also showed no difference between the numbers of fungal isolates obtained from infructescences in the unburnt and recently burnt plots $\left(\mathrm{X}^{2}=1.42 ; \mathrm{df}=1 ; \mathrm{P}=0.23\right)$. 

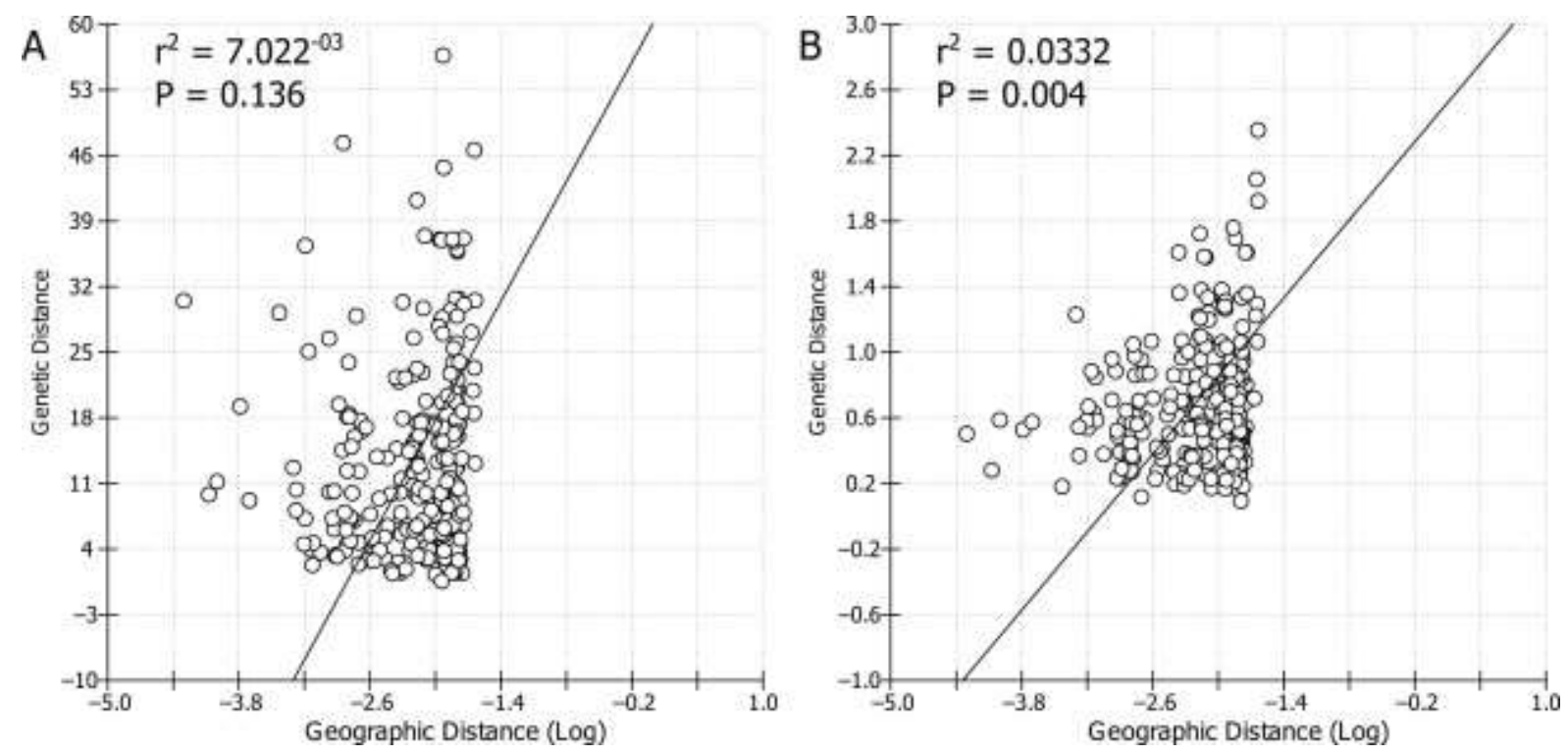

Fig 3 : Correlations to test isolation-by-distance. The $\delta \mu^{2}$ genetic distance (Goldstein et al. 1995) (A) and Nei's unbiased standard genetic distance (Nei 1978) (B) between Knoxdaviesia proteae isolates in the different sampling plots versus the logarithmic geographic distance between the midpoints of these plots.

Without incorporation of the LOCPRIOR model, STRUCTURE could not detect significant population structure. When considering the origin of $K$. proteae isolates (unburnt or recently burnt area), both $\mathrm{L}(K)$ and $\Delta K$ designated $K=3$ as the most likely number of clusters. Inspection of the cluster assignment (Fig 4A) indicated that each cluster contained 106 fungal individuals - i.e. the genotype of each individual was distributed among the three clusters. However, in each case only one of the three clusters contained the majority (> 70\%) of an individual's genotype. All of the individuals from the unburnt and most from burnt areas had the majority of their genotype assigned to the green cluster. Eleven individuals from the burnt area were predominantly assigned to either the dark blue or light blue cluster. The MSN (Fig 5) displayed a cohesive assemblage of fungi with numerous loops in the network linking different genotypes. The index of linkage disequilibrium was not significantly different from zero $\left(\overline{\mathrm{r}}_{\mathrm{d}}=6.7^{-3} ; \mathrm{P}=0.33\right.$; Fig $\left.6 \mathrm{~A}\right)$, supporting the null hypothesis of random recombination. 
A

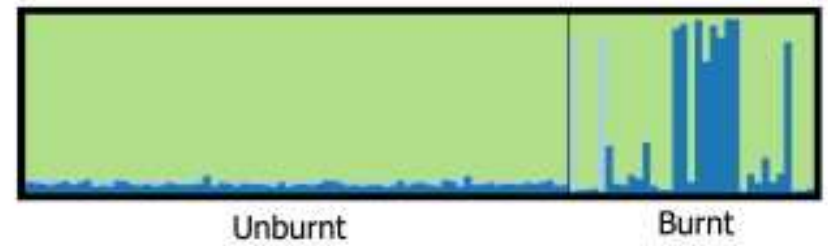

B

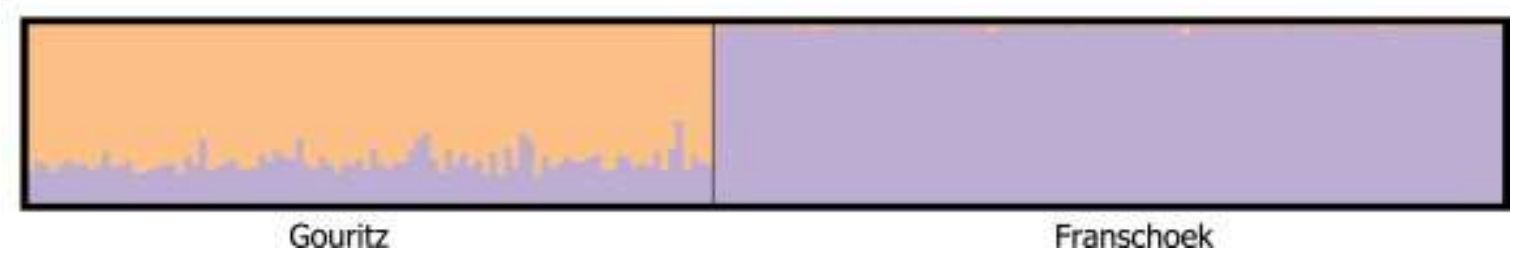

Fig 4 : Histograms depicting the inferred vector $Q$ using STRUCTURE 2.3.4 ( Falush et al., 2003, Falush et al., 2007, Hubisz et al., 2009 and Pritchard et al., 2000). The proportion of an individual's genotype that originates from each inferred cluster is indicated on the y-axis while each vertical bar represents an individual. The clusters detected are indicated with different colours. A) In Franschoek, all isolates from unburnt areas and most isolates from recently burnt areas are predominantly assigned to one cluster (green). Two additional clusters (light and dark blue), present only at low levels in the unburnt area, were predominant in eleven individuals in the recently burnt area. B) Assignment of all K. proteae individuals based on their population of origin (Gouritz or Franschoek).

\subsection{Dispersal between distantly separated populations}

In an earlier $K$. proteae population study, only two identical genotypes were identified in the population (Aylward et al., 2014b). The same phenomenon was found in the current study as 105 unique genotypes were observed out of the 106 sampled isolates. In the combined Gouritz and Franschoek dataset, shared genotypes were not detected with each individual having at least one private allele in its genotype and the majority of alleles were shared between the populations (Fig 2B). Additionally, the number of effective alleles $\left(\mathrm{N}_{\mathrm{e}}\right)$ calculated for the two populations combined was not significantly different from that of the two separate populations, indicating similar genetic compositions (Fig 2B). The population differentiation measurements $\Delta_{\mathrm{ST}}$ and $\Delta_{\mathrm{S}} / \Delta_{\mathrm{T}}$ did not provide evidence of genetic isolation (Table 2). However, the non-zero value of Jost's D and $\mathrm{D}_{\text {est(hap) }}$ and the significance of theta suggested some level of differentiation, albeit low, between the Gouritz and Franschoek populations of $K$. proteae (Table 2).

In STRUCTURE, Bayesian inference alone could not detect a difference between the two populations, but incorporation of the LOCPRIOR model revealed $K=2$ as most likely (based on both $\mathrm{L}(K)$ and $\Delta K$ ). Using this method, all $K$. proteae individuals could be assigned to their 
population of origin (Fig 4B), although all individuals contained elements from both clusters. The inability of STRUCTURE to separate the two populations without prior information of each individual's origin is indicative of weak population structure and is therefore congruent with the measures of differentiation. The constructed MSN (Fig S2) also displayed numerous loops and cohesiveness as observed in the networks for the individual populations (Fig 5; Aylward et al., 2014b). Its failure to cluster the Gouritz and Franschoek populations separately also supports a weak population structure and high similarity between the two populations. The test for random recombination could not reject the null hypothesis $\left(\overline{\mathrm{r}}_{\mathrm{d}}=-2^{-4}\right.$; $\mathrm{P}=0.66$; Fig 6B) and, therefore, indicates general outcrossing between $K$. proteae individuals from the two distantly separated populations.

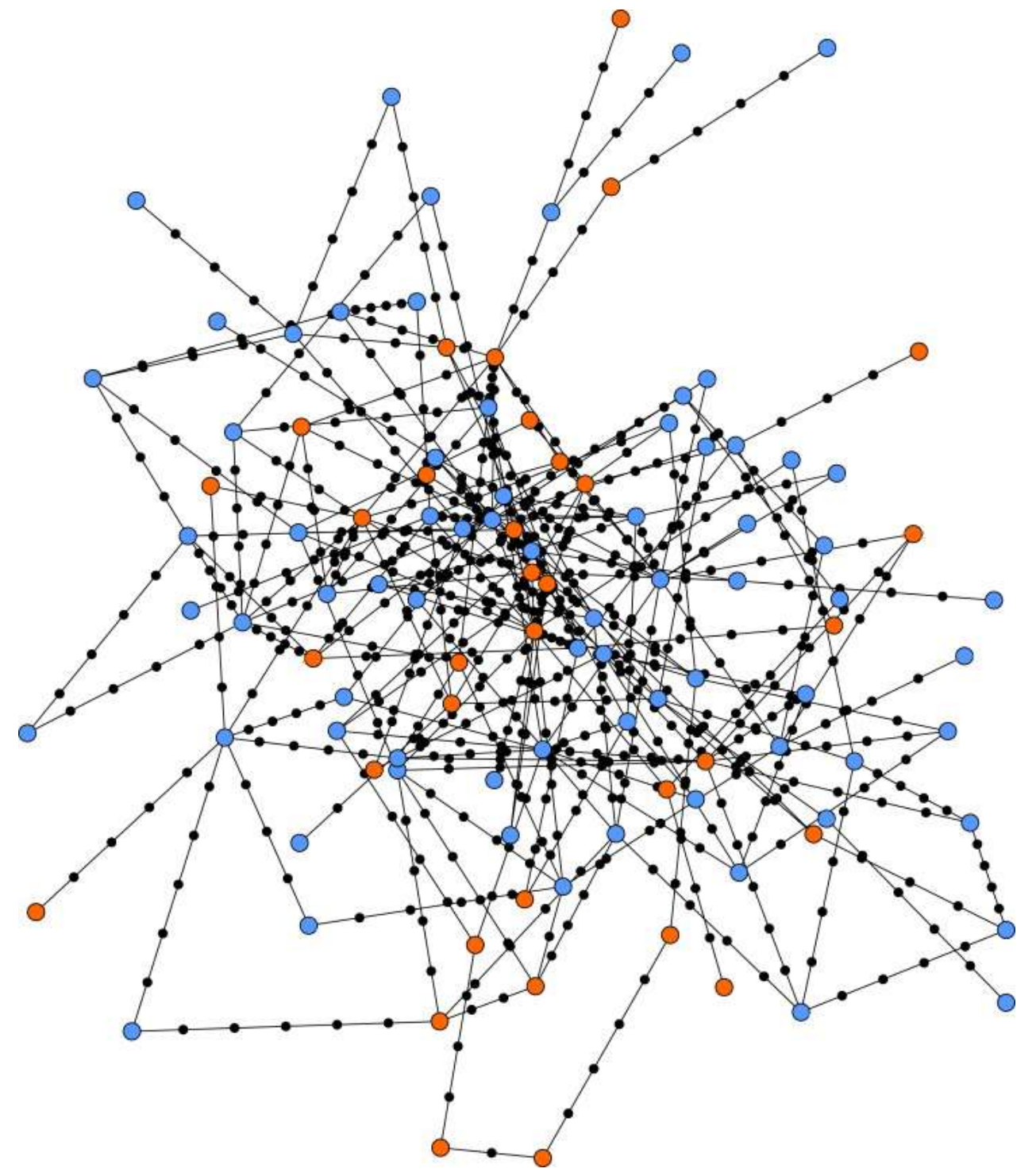

Fig 5: Minimum spanning network (MSN) depicting the relationships between 105 unique genotypes encountered in the Franschoek Knoxdaviesia proteae population. Black dots represent missing genotypes. Genotypes from the unburnt and recently burnt areas are shaded blue and orange, respectively. 

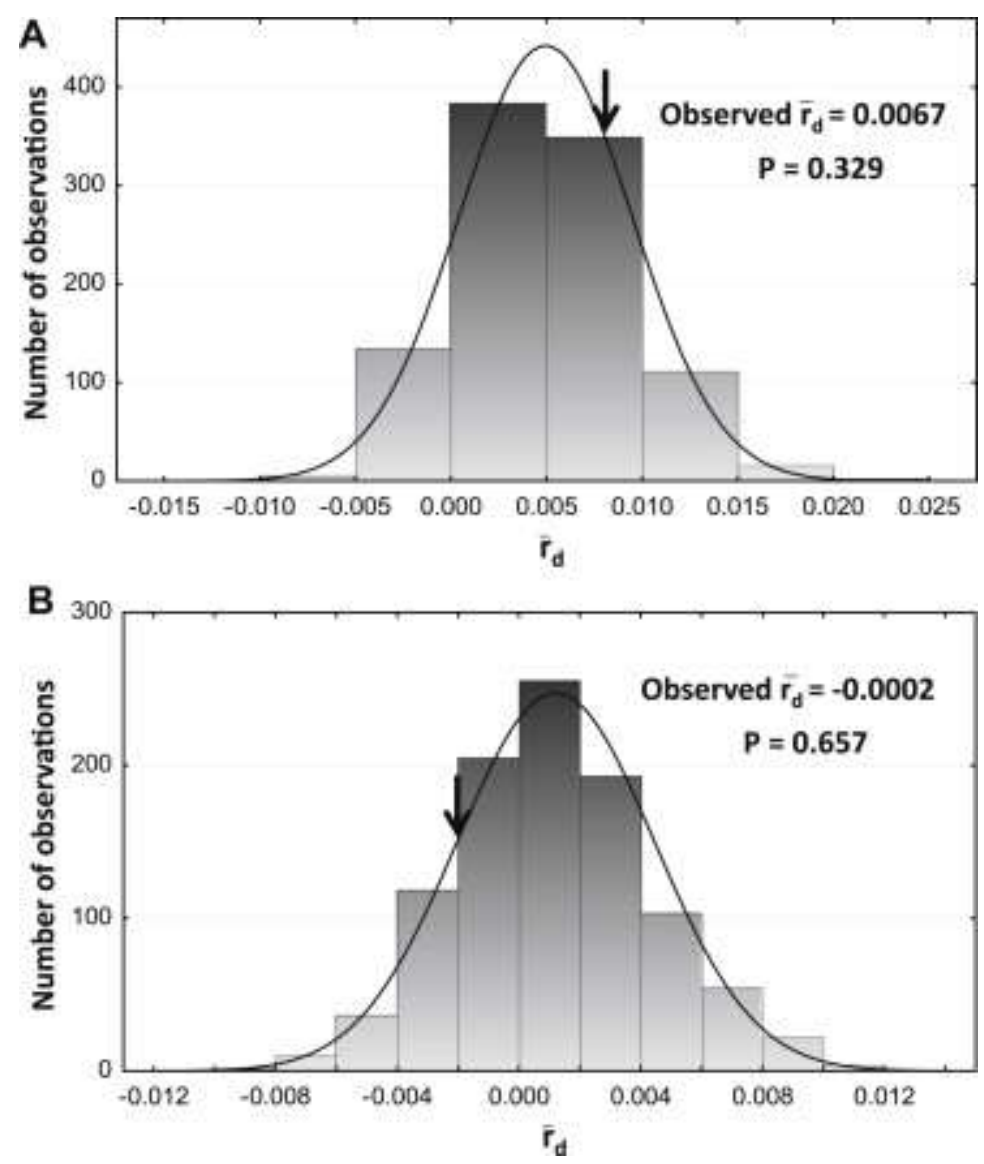

Fig 6 : Observed values of the index of linkage disequilibrium, $\overline{\mathbf{r}}_{\mathfrak{d}}$ for (A) the Franschoek and (B) Gouritz and Franschoek Knoxdaviesia proteae populations. Observed values are indicated on a normal distribution of $\overline{\mathbf{r}}_{\mathfrak{d}}$ values calculated for 1000 randomly generated datasets.

\section{Discussion}

\subsection{Recolonization of recently burnt areas}

Landscapes that experience prolonged dry conditions, such as Mediterranean, grassland savannah and even some forest areas, are prone to fire damage (Bond \& Keeley, 2005). It is, therefore, surprising that this study appears to be the first to consider post-fire recolonization of plant-associated fungi. Investigations into the effect of fire on soil microbial biomass in Mediterranean regions (Dumontet et al., 1996) have revealed that fungi are more susceptible to fire and re-establish less easily than bacteria (Bárcenas-Moreno et al., 2011; Guerrero et al., 2005). The niche space availability and elimination of competition provided by fire, however, apparently facilitates rapid re-establishment.

The genetic and genotypic diversity of $K$. proteae described in burnt and unburnt areas was remarkably high. This is consistent with the results of the Gouritz population study (Aylward et al., 2014b) where heterozygosity was $0.74 \pm 0.04$ and the maximum percentage of 
genotypic diversity $(\hat{\mathrm{G}})$ was $97.87 \%$. Contrary to the reduced variation usually observed in recently introduced populations (Dlugosch \& Parker, 2008), the individual genetic diversities and composition of the burnt and unburnt populations were similar. However, the lack of population differentiation suggests that the recently burnt population is primarily a subset of the adjacent unburnt population. This view is supported by the presence of significantly fewer unique alleles in the burnt populations, which suggests that the fungal populations in the recently burnt sites are primarily derived from the unburnt area and have experienced a genetic bottleneck (Black et al., 1988). The few unique alleles that were detected in the burnt area, however, support the two additional genetic clusters detected by STRUCTURE. Together, they suggest that sources of fungal inoculants other than those from adjacent established populations could play a role in recolonization.

Numerous $K$. proteae migrants within and between the burnt and unburnt areas explain the closely related and weakly structured population. The effects of genetic drift seem to be masked by a high level of gene flow (Slatkin, 1987). The high level of genetic variation within the population is probably due to the reproductive strategy of $K$. proteae. Both the asexual and sexual states of $K$. proteae occur in P. repens infructescences (Wingfield et al., 1988), but the high genetic and genotypic diversity of the population is explained by sexual outcrossing being the predominant mode of reproduction. Whether $K$. proteae is homothallic (able to self-fertilize) or heterothallic (obligatory outcrossing) has yet to be determined, but would provide further information concerning the population biology of this organism.

Adjacent unburnt areas appear to be the primary source of fungal inoculants for recently burnt regions. Isolation-by-distance (IBD) is a result of limited dispersal across the landscape (Wright, 1943) and in three instances such limited dispersal was revealed between the unburnt and recently burnt areas. These three tests were, however, based on the Infinite Alleles Model (IAM), a model probably less suited to perfect microsatellites than the Stepwise Mutation Model (SMM) described by Shriver et al. (1993) that was also used. The true situation is probably provided by an intermediate between the results emerging from these two models and, since weak IBD was detected in a minority of cases, limited dispersal from the unburnt to the burnt area is unlikely. The lack of (or very weak) IBD pattern observed indicates that $P$. repens plants closer to unburnt areas are not recolonized more readily. In fact, recolonization appears to be a result of widespread dispersal and is therefore primarily long-distance-orientated. This strengthens the premise that long-distance dispersal is the predominant influence in recolonization of burnt areas. 


\subsection{Long-distance dispersal between distant $K$. proteae populations}

The high level of genetic similarity between the K. proteae population in Gouritz and the burnt/unburnt Franschoek population was unexpected because these two sampling areas are separated by $240 \mathrm{~km}$ and mountainous geographic barriers. Although the two populations do not appear completely panmictic (randomly interbreeding), their genetic diversities and compositions were alike and population differentiation was low. Also, recombination between fungi in the two populations appears to have occurred frequently, since all $K$. proteae individuals from the combined populations showed random mating and interconnected genotypes based on the Minimum Spanning Network (MSN). Although knowledge about the dispersal of the vectors of $K$. proteae is scarce, it appears that the dispersal of this ophiostomatoid fungus follows a fat-tailed kernel in which long-distance dispersal events are not rare (Klein et al., 2006). In such a case, recolonization would be due to the influence of inoculants from several sources that maintain genetic diversity during the recolonization process (Szövényi et al., 2012).

Long-distance dispersal is a common trait in fungi that disperse via air or water and is wellstudied for plant pathogenic fungi (Brown \& Hovmøller, 2002). Human activity and movement of plant materials is also commonly implicated in the dispersal of fungi and has resulted in the spread of devastating pathogens between countries and continents (Brown \& Hovmøller, 2002; Wingfield et al., 2001; 2010). Examples of migration at an intercontinental or even global scale are available for lichen-forming (Buschbom, 2007), saprobic (Moncalvo \& Buchanan, 2008), ectomycorrhizal (Moyersoen et al., 2003) and marine fungi (Pang et al., 2013). Extreme long-distance dispersal of arthropod-vectored fungi in the absence of human involvement is, however, unlikely. The high level of relatedness between the two populations in this study, therefore, probably demands reconsideration of the vectors known to disperse $K$. proteae. Dispersal via flying insects, especially robust beetles such as Genuchus hottentotus (F.), Trichostetha fascicularis L. and T. capensis L. (Roets et al., 2009a), may allow substantial contact between fungal individuals in a population and facilitate a high number of migration events. It is, however, difficult to attribute the extent of admixture observed between these distantly separated $K$. proteae populations to beetles alone, particularly given the structured populations observed in other ophiostomatoid fungi with beetle vectors (Lee et al., 2007; Morin et al., 2004; Tsui et al., 2012). Additionally, these beetles are unlikely to fly great distances, at least not in large numbers. 
Ultimately, the dispersal of Knoxdaviesia species is linked to the behaviour of the mites that act as their primary vectors. Due to their small size, autonomous dispersal is not effective and most mites utilize either wind or habitat-specific vectors as dispersal vehicles (Mitchell, 1970). Many mites are known to associate with birds for phoresy (Krantz \& Walter, 2009; Proctor \& Owens, 2000) and this relationship has been documented between birds and mites associated with Protea species (Collins \& Rebelo, 1987; N. Theron, pers. com.). It is therefore possible that mites carrying ophiostomatoid fungi are not exclusively phoretic on beetles, but also on birds. Since birds are able to travel further than beetles, involvement of Protea-pollinating birds, such as sunbirds and sugarbirds (Collins \& Rebelo, 1987), in the dispersal of ophiostomatoid fungi could explain the widespread gene flow between these two distantly separated populations. The cape sugarbird, Promerops cafer, and the malachite sunbird, Nectarinia famosa, have both been noted to fly to $160 \mathrm{~km}$ (Fraser et al., 1989; Harrison et al., 1997) within the Core Cape Subregion (CCR) and would be good candidates for further investigation of this hypothesis.

The question arises as to how the small, primary mite vectors of Knoxdaviesia species would accomplish such extensive dispersal, even considering phoresy on larger arthropods or birds. It is possible that successive migration events between interspersed $K$. proteae populations or transfer of mites between birds (Proctor \& Owens, 2000) could lead to gene flow over distances far exceeding the capacity of one pollinator. In fact, multiple introductions of $K$. proteae, both from the unburnt to the burnt area and between the two $K$. proteae populations, seems to explain the patterns of gene flow and genetic diversity observed in this study (Dlugosch \& Parker, 2008). Considering the dual dispersal system available to the ophiostomatoid fungi, numerous fungal inoculants are expected. A single beetle can carry a large number of mites (> 100) (Roets et al., 2009a; 2011) and thereby facilitate many migration events. Individual mites may even carry more than one fungal strain, further increasing the potential number of fungal migrants.

\section{Conclusions}

Knoxdaviesia proteae colonizers of $P$. repens infructescences arise primarily from plants in adjacent unburnt areas. Although the K. proteae population in the recently burnt area considered in this study is primarily a subset of its neighbouring unburnt population, our data suggest that inoculants were also introduced from other areas by long-distance dispersal. 
Long-distance dispersal further remained prevalent even over large distances and across geographic barriers, although fungal panmixia was not perfectly maintained. In addition to beetles that are already known to carry mites vectoring Protea-associated ophiostomatoid fungi, avian Protea pollinators may therefore also play a significant role in the phoresy of ophiostomatoid mite vectors. Ultimately, the lack of population structure appears to be a result of multiple fungal introductions and sexual outcrossing. Future studies should include $K$. proteae populations across the natural range of its host and examine IBD at this larger spatial scale.

Since the agents responsible for long-distance dispersal of fungal spores (i.e., beetles and presumably passerine birds) are also carriers of Protea pollen, the gene flow observed for $K$. proteae between $P$. repens populations may also reflect gene flow for the plants themselves. As a result, $P$. repens plants separated by the same distance and geographic barriers as the two $K$. proteae populations may be similarly structured to the fungi. This study could therefore guide future studies on the population genetics of this iconic and economically important (Coetzee \& Littlejohn, 2001; Knoesen \& Conradie, 2009) CCR plant.

\section{Acknowledgements}

The National Research Foundation (NRF) and the Department of Science and Technology (DST)-NRF Centre of Excellence in Tree Health Biotechnology (CTHB) are acknowledged for financial support. We thank the Western Cape Nature Conservation Board for the necessary collection permits and two anonymous reviewers for their comments on this manuscript.

\section{References}

Agapow, P-M, Burt, A, 2001. Indices of multilocus linkage disequilibrium. Molecular Ecology Notes 1: 101-102.

Atkins, M, 1961. A Study of the Flight of the Douglas-fir Beetle Dendroctonus pseudotsugae Hopk. (Coleoptera: Scolytidae): III Flight Capacity. The Canadian Entomologist 93: 467-474.

Aylward, J, Dreyer, LL, Steenkamp, ET, Wingfield, MJ, Roets, F, 2014a. Development of polymorphic microsatellite markers for the genetic characterisation of Knoxdaviesia proteae (Ascomycota: Microascales) using ISSR-PCR and pyrosequencing. Mycological Progress 13: 439-444.

Aylward, J, Dreyer, LL, Steenkamp, ET, Wingfield, MJ, Roets, F, 2014b. Panmixia defines the genetic diversity of a unique arthropod-dispersed fungus specific to Protea flowers. Ecology and Evolution 4: 3444-3455. 
Bárcenas-Moreno, G, García-Orenes, F, Mataix-Solera, J, Mataix-Beneyto, J, Bååth, E, 2011. Soil microbial recolonisation after a fire in a Mediterranean forest. Biology and Fertility of Soils 47: 261-272.

Black, WC, Ferrari, JA, Rai, KS, Sprenger, D, 1988. Breeding structure of a colonising species: Aedes albopictus (Skuse) in the United States. Heredity 60: 173-181.

Bond, WJ, Keeley, JE, 2005. Fire as a global 'herbivore': the ecology and evolution of flammable ecosystems. Trends in Ecology \& Evolution 20: 387-394.

Brown, JK, Hovmøller, MS, 2002. Aerial dispersal of pathogens on the global and continental scales and its impact on plant disease. Science 297: 537-541.

Buschbom, J, 2007. Migration between continents: geographical structure and long-distance gene flow in Porpidia flavicunda (lichen-forming Ascomycota). Molecular Ecology 16: $1835-1846$.

Byers, JA, 1996. An encounter rate model of bark beetle populations searching at random for susceptible host trees. Ecological Modelling 91: 57-66.

Cassar, S, Blackwell, M, 1996. Convergent Origins of Ambrosia Fungi. Mycologia 88: 596601.

Chakraborty, R, Jin, L, 1992. Heterozygote deficiency, population substructure and their implications in DNA fingerprinting. Human Genetics 88: 267-272.

Coetzee, JH, Giliomee, JH, 1985. Insects in association with the inflorescence of Protea repens (L.) (Proteaceae) and their role in pollination. Journal of the Entomological Society of South Africa 48: 303-314.

Coetzee, JH, Littlejohn, GM, 2001. Protea: A floricultural crop from the Cape Floristic Kingdom. Horticultural Reviews 26: 1-48.

Collins, BG, Rebelo, T, 1987. Pollination biology of the Proteaceae in Australia and southern Africa. Australian Journal of Ecology 12: 387-421.

Cowling, RM (Eds.), 1992. The ecology of fynbos: Nutrients, fire and diversity, Oxford University Press, Cape Town.

Cowling, RM, Richardson, DM, 1995. Fynbos: South Africa's unique floral kingdom. Fernwood Press, Vlaeberg.

Crawford, NG, 2010. SMOGD: software for the measurement of genetic diversity. Molecular Ecology Resources 10: 556-557.

Crous, PW, Summerell, BA, Shivas, RG, Burgess, TI, Decock, CA, Dreyer, LL, Granke, LL, Guest, DI, Hardy, GESTJ, Hausbeck, MK, Hüberli, D, Jung, T, Koukol, O, Lennox, CL, Liew, ECY, Lombard, L, McTaggart, AR, Pryke, JS, Roets, F, Saude, C, Shuttleworth, LA, Stukely, MJC, Vánky, K, Webster, BJ, Windstam, ST, Groenewald, JZ, 2012. Fungal Planet description sheets: 107-127. Persoonia 28: 138182.

Day, J, Siegfried, WR, Louw, GN, Jarman, ML (Eds.), 1979. Fynbos ecology: a preliminary synthesis, CSIR, SANSP Report 40, National Scientific Programmes Unit.

De Beer, ZW, Seifert, KA, Wingfield, MJ, 2013. A nomenclature for ophiostomatoid genera and species in the Ophiostomatales and Microascales, in: Seifert, KA, de Beer, ZW, Wingfield, MJ (Eds.), Ophiostomatoid fungi: expanding frontiers. CBS Biodiversity Series, pp. 245-322.

Dieringer, D, Schlötterer, C, 2003. Microsatellite analyser (MSA): a platform independent analysis tool for large microsatellite data sets. Molecular Ecology Notes 3: 167-169.

Dlugosch, KM, Parker, IM, 2008. Founding events in species invasions: genetic variation, adaptive evolution, and the role of multiple introductions. Molecular Ecology 17: 431-449. 
Dumontet, S, Dinel, H, Scopa, A, Mazzatura, A, Saracino, A, 1996. Post-fire soil microbial biomass and nutrient content of a pine forest soil from a dunal Mediterranean environment. Soil Biology and Biochemistry 28: 1467-1475.

Earl, DA, von Holdt, BM, 2012. STRUCTURE HARVESTER: a website and program for visualizing STRUCTURE output and implementing the Evanno method. Conservation Genetics Resources 4: 359-361.

Ersts, PJ, 2014. Geographic Distance Matrix Generator (version 1.2.3). American Museum of Natural History, Center for Biodiversity and Conservation. http://biodiversityinformatics.amnh.org/open_source/gdmg.

Evanno, G, Regnaut, S, Goudet, J, 2005. Detecting the number of clusters of individuals using the software STRUCTURE: a simulation study. Molecular Ecology 14: 26112620.

Excoffier, L, Lischer, HEL, 2010. Arlequin suite ver 3.5: a new series of programs to perform population genetics analyses under Linux and Windows. Molecular Ecology Resources 10: 564-567.

Falush, D, Stephens, M, Pritchard, JK, 2003. Inference of Population Structure Using Multilocus Genotype Data: Linked Loci and Correlated Allele Frequencies. Genetics 164: 1567-1587.

Falush, D, Stephens, M, Pritchard, JK, 2007. Inference of population structure using multilocus genotype data: dominant markers and null alleles. Molecular Ecology Notes 7: 574-578.

Forsse, E, Solbreck, C, 1985. Migration in the bark beetle Ips typographus L.: duration, timing and height of flight. Zeitschrift für angewandte Entomologie 100: 47-57.

Fraser, MW, McMahon, L, Underhill, LG, Underhill, GD, Rebelo, AG, 1989. Nectarivore ringing in the southwestern Cape. Safring News 18: 3-18.

Goldstein, DB, Ruiz Linares, A, Cavalli-Sforza, LL, Feldman, MW, 1995. An evaluation of genetic distances for use with microsatellite loci. Genetics 139: 463-471.

Grünwald, NJ, Goodwin, SB, Milgroom, MG, Fry, WE, 2003. Analysis of genotypic diversity data for populations of microorganisms. Phytopathology 93: 738-746.

Guerrero, C, Mataix-Solera, J, Gómez, I, García-Orenes, F, Jordán, MM, 2005. Microbial recolonization and chemical changes in a soil heated at different temperatures. International Journal of Wildland Fire 14: 385-400.

Harrison, JA, Allan, DG, Underhill, LG, Herremans, M, Tree, AJ, Parker, V, Brown, CJ (Eds.), 1997. The Atlas of Southern African Birds, vol. 2. Passerines, BirdLife South Africa, Johannesburg.

Hubisz, MJ, Falush, D, Stephens, M, Pritchard, JK, 2009. Inferring weak population structure with the assistance of sample group information. Molecular Ecology Resources 9: 1322-1332.

Jakobsson, M, Rosenberg, NA, 2007. CLUMPP: a cluster matching and permutation program for dealing with label switching and multimodality in analysis of population structure. Bioinformatics 23: 1801-1806.

Jensen, J, Bohonak, A, Kelley, S, 2005. Isolation by distance, web service. BMC Genetics $\mathbf{6}$ : 13.

Jost, L, 2008. G ST $_{\text {and }}$ its relatives do not measure differentiation. Molecular Ecology 17: 4015-4026.

Kamvar, ZN, Tabima, JF, Grünwald, NJ, 2013. Poppr: An R package for genetic analysis of populations with mixed (clonal/sexual) reproduction. $\mathrm{R}$ package version 3.0.2. http://cran.r-project.org/package=poppr.

Keeley, JE, 1995. Seed-Germination Patterns in Fire-Prone Mediterranean-Climate Regions, in: Arroyo, MTK, Zedler, PH, Fox, MD, Keeley, JE (Eds.), Ecology and 
Biogeography of Mediterranean Ecosystems in Chile, California, and Australia. Springer, New York, pp. 239-273.

Kimura, M, Crow, JF, 1964. The number of alleles that can be maintained in a finite population. Genetics 49: 725-738.

Klein, EK, Lavigne, C, Gouyon, P-H, 2006. Mixing of propagules from discrete sources at long distance: comparing a dispersal tail to an exponential. BMC ecology 6: 3 .

Knoesen, H, Conradie, B, 2009. A survey of the cultivation and wild harvesting of fynbos flowers in South Africa. Available from: www.flowervalley.org.za/pdfs.

Krantz, GW, Walter, DE, 2009. A Manual of Acarology, 3 ed. Texas Tech University Press, Lubbock, Texas.

Kruger, FJ, Reid, P, Mayet, M, Alberts, W, Goldhammer, JG, Tolhurst, K, 2000. A review of the veld fires in the Western Cape during 15 to 25 January 2000. Department of Water Affairs and Forestry, Pretoria, South Africa.

Le Maitre, DC, Midgley, JJ, 1992. Plant reproductive ecology, in: Cowling, RM (Ed.), Fynbos, fire and diversity. Oxford University Press, Cape Town, pp. 135-174.

Lee, S, Groenewald, JZ, Taylor, JE, Roets, F, Crous, PW, 2003. Rhynchostomatoid fungi occurring on Proteaceae. Mycologia 95: 902-910.

Lee, S, Hamelin, RC, Six, DL, Breuil, C, 2007. Genetic diversity and the presence of two distinct groups in Ophiostoma clavigerum associated with Dendroctonus ponderosae in British Columbia and the Northern Rocky Mountains. Phytopathology 97: 11771185.

Lee, S, Roets, F, Crous, PW, 2005. Biodiversity of saprobic microfungi associated with the infructescences of Protea species in South Africa. Fungal Diversity 19: 69-78.

Marais, GJ, 1996. Fungi associated with the infructescences of Protea species with special reference to the Ophiostomatales. PhD Thesis, University of the Orange Free State, Bloemfontein, South Africa.

Marais, GJ, Wingfield, MJ, 2001. Ophiostoma africanum sp. nov., and a key to ophiostomatoid species from Protea infructescences. Mycological Research 105: 240246.

Marincowitz, S, Crous, PW, Groenewald, JZ, Wingfield, MJ, 2008. Microfungi occurring on Proteaceae in the fynbos. CBS Fungal Biodiversity Centre, Utrecht.

McDonald, BA, Miles, J, Nelson, LR, Pettway, RE, 1994. Genetic variability in nuclear DNA in field populations of Stagonospora nodorum. Phytopathology 84: 250-255.

Mitchell, R, 1970. An analysis of dispersal in mites. The American Naturalist 104: 425-431.

Moncalvo, J-M, Buchanan, PK, 2008. Molecular evidence for long distance dispersal across the Southern Hemisphere in the Ganoderma applanatum-australe species complex (Basidiomycota). Mycological Research 112: 425-436.

Morin, C, Breuil, C, Bernier, L, 2004. Genetic Variability and Structure of Canadian Populations of the Sapstain Fungus Ceratocystis resinifera. Phytopathology 94: 13231330.

Moyersoen, B, Beever, RE, Martin, F, 2003. Genetic diversity of Pisolithus in New Zealand indicates multiple long-distance dispersal from Australia. New Phytologist 160: 569579.

Nei, M, 1978. Estimation of average heterozygosity and genetic distance from a small number of individuals. Genetics 89: 583-590.

Nei, M, Chesser, RK, 1983. Estimation of fixation indices and gene diversities. Annals of Human Genetics 47: 253-259.

Pang, K-L, Vrijmoed, LL, Jones, EG, 2013. Genetic variation within the cosmopolitan aquatic fungus Lignincola laevis (Microascales, Ascomycota). Organisms Diversity \& Evolution 13: 301-309. 
Peakall, R, Smouse, PE, 2006. GenAlEx 6: genetic analysis in Excel. Population genetic software for teaching and research. Molecular Ecology Notes 6: 288-295.

Peakall, R, Smouse, PE, 2012. GenAlEx 6.5: genetic analysis in Excel. Population genetic software for teaching and research - an update. Bioinformatics 28: 2537-2539.

Pritchard, JK, Stephens, M, Donnelly, P, 2000. Inference of Population Structure Using Multilocus Genotype Data. Genetics 155: 945-959.

Proctor, H, Owens, I, 2000. Mites and birds: diversity, parasitism and coevolution. Trends in Ecology \& Evolution 15: 358-364.

R Core Team, 2014. R: A language and environment for statistical computing. R Foundation for Statistical Computing, Vienna, Austria. http://www.R-project.org.

Rebelo, T, 1995. Proteas: A field guide to the Proteas of Southern Africa. Fernwood Press, Vlaeberg, South Africa.

Roets, F, Crous, PW, Wingfield, MJ, Dreyer, LL, 2009a. Mite-mediated hyperphoretic dispersal of Ophiostoma spp. from the Infructescences of South African Protea spp. Environmental Entomology 28: 143-152.

Roets, F, de Beer, ZW, Dreyer, LL, Zipfel, R, Crous, PW, Wingfield, MJ, 2006a. Multi-gene phylogeny for Ophiostoma spp. reveals two new species from Protea infructescences. Studies in Mycology 55: 199-212.

Roets, F, Dreyer, LL, Crous, PW, 2005. Seasonal trends in colonisation of Protea infructescences by Gondwanamyces and Ophiostoma spp. South African Journal of Botany 71: 307-311.

Roets, F, Dreyer, LL, Geertsema, H, Crous, PW, 2006b. Arthropod communities in Proteaceae infructescences: seasonal variation and the influence of infructescence phenology. African Entomology 14: 257-265.

Roets, F, Wingfield, BD, de Beer, ZW, Wingfield, M, Dreyer, LL, 2010. Two new Ophiostoma species from Protea caffra in Zambia. Persoonia 24: 18-28.

Roets, F, Wingfield, MJ, Crous, PW, Dreyer, LL, 2007. Discovery of Fungus-Mite Mutualism in a Unique Niche. Environmental Entomology 36: 1226-1237.

Roets, F, Wingfield, MJ, Crous, PW, Dreyer, LL, 2009b. Fungal radiation in the Cape Floristic Region: An analysis based on Gondwanamyces and Ophiostoma. Molecular Phylogenetics and Evolution 51: 111-119.

Roets, F, Wingfield, MJ, Crous, PW, Dreyer, LL, 2013. Taxonomy and ecology of ophiostomatoid fungi associated with Protea infructescences, in: Seifert, KA, de Beer, ZW, Wingfield, MJ (Eds.), Ophiostomatoid fungi: expanding frontiers. CBS Biodiversity Series, Utrecht, The Netherlands, pp. 177-187.

Roets, F, Wingfield, MJ, Wingfield, BD, Dreyer, LL, 2011. Mites are the most common vectors of the fungus Gondwanamyces proteae in Protea infructescences. Fungal Biology 115: 343-350.

Rosenberg, NA, 2004. DISTRUCT: a program for the graphical display of population structure. Molecular Ecology Notes 4: 137-138.

Rousset, F, 1997. Genetic differentiation and estimation of gene flow from F-statistics under isolation by distance. Genetics 145: 1219-1228.

Shriver, MD, Jin, L, Chakraborty, R, Boerwinkle, E, 1993. VNTR allele frequency distributions under the stepwise mutation model: a computer simulation approach. Genetics 134: 983-993.

Slatkin, M, 1987. Gene flow and the geographic structure of natural populations. Science 236: 787-792.

Southey, D, 2009. Wildfires in the Cape Floristic Region: Exploring vegetation and weather as drives of fire frequency. MSc Thesis, Department of Botany, University of Cape Town. 
Stoddart, JA, Taylor, JF, 1988. Genotypic diversity: estimation and prediction in samples. Genetics 118: 705-711.

Szövényi, P, Sundberg, S, Shaw, AJ, 2012. Long-distance dispersal and genetic structure of natural populations: an assessment of the inverse isolation hypothesis in peat mosses. Molecular Ecology 21: 5461-5472.

Taylor, JW, Geiser, DM, Burt, A, Koufopanou, V, 1999. The Evolutionary Biology and Population Genetics Underlying Fungal Strain Typing. Clinical Microbiology Reviews 12: 126-146.

Teacher, AGF, Griffiths, DJ, 2011. HapStar: automated haplotype network layout and visualization. Molecular Ecology Resources 11: 151-153.

Theron, N, Roets, F, Dreyer, LL, Esler, KJ, Ueckermann, EA, 2012. A new genus and eight new species of Tydeoidea (Acari: Trombidiformes) from Protea species in South Africa. International Journal of Acarology 38: 257-273.

Tsui, CKM, Roe, AD, El-Kassaby, YA, Rice, AV, Alamouti, SM, Sperling, FAH, Cooke, JEK, Bohlmann, J, Hamelin, RC, 2012. Population structure and migration pattern of a conifer pathogen, Grosmannia clavigera, as influenced by its symbiont, the mountain pine beetle. Molecular Ecology 21: 71-86.

Turchin, P, Thoeny, WT, 1993. Quantifying dispersal of southern pine beetles with markrecapture experiments and a diffusion model. Ecological Applications 3: 187-198.

Wilgen, B, Richardson, D, Kruger, F, Hensbergen, H, Wilgen, BW, Forsyth, GG, 1992. Regeneration strategies in fynbos plants and their influence on the stability of community boundaries after fire, Fire in South African mountain fynbos: ecosystem, community, and species response at Swartboskloof. Springer, Berlin Heidelberg, pp. 54-80.

Wingfield, BD, Viljoen, CD, Wingfield, MJ, 1999. Phylogenetic relationships of ophiostomatoid fungi associated with Protea infructescences in South Africa. Mycological Research 103: 1616-1620.

Wingfield, MJ, Slippers, B, Roux, J, Wingfield, BD, 2001. Worldwide Movement of Exotic Forest Fungi, Especially in the Tropics and the Southern Hemisphere. BioScience 51: 134-140.

Wingfield, MJ, Slippers, B, Wingfield, BD, 2010. Novel associations between pathogens, insects and tree species threaten world forests. New Zealand Journal of Forestry Science 40 suppl.: S95-S103.

Wingfield, MJ, Wyk, PSV, Marasas, WFO, 1988. Ceratocystiopsis proteae sp. nov., with a new anamorph genus. Mycologia 80: 23-30.

Wright, S, 1943. Isolation by Distance. Genetics 28: 139-156.

Yeh, FC, Yang, RC, Boyle, T, Ye, ZH, Mao, JX, 1999. POPGENE, version 1.32: the user friendly software for population genetic analysis. Molecular Biology and Biotechnology Centre, University of Alberta, Edmonton, AB, Canada. 


\section{Supplementary Material}

Table S1 - Number of Knoxdaviesia proteae isolates obtained from the different sampling plots in Franschoek Mountain.

\begin{tabular}{ccccc}
\hline \multicolumn{2}{c}{ Unburnt } & & \multicolumn{2}{c}{ Burnt } \\
\cline { 1 - 2 } Plot & Isolates & & Plot & Isolates \\
1 & 0 & & 4 & 2 \\
2 & 0 & & 6 & 0 \\
3 & 3 & & 13 & 0 \\
5 & 7 & & 14 & 1 \\
7 & 2 & & 15 & 0 \\
8 & 4 & & 16 & 0 \\
9 & 10 & & 24 & 9 \\
10 & 7 & & 25 & 2 \\
11 & 5 & & 26 & 9 \\
12 & 1 & & 29 & 9 \\
17 & 6 & & 30 & 1 \\
18 & 0 & & \\
19 & 2 & & \\
20 & 5 & & \\
21 & 3 & & \\
22 & 4 & & \\
23 & 4 & & \\
27 & 7 & & \\
28 & 3 & & \\
Total & 73 & & \\
\hline
\end{tabular}


Table S2 - Results of the Mantel tests ${ }^{A}$ conducted between individual unburnt plots and recently burnt plots.

\begin{tabular}{|c|c|c|c|c|c|c|c|c|}
\hline \multirow[b]{2}{*}{$\begin{array}{c}\text { Unburnt } \\
\text { sampling plots }\end{array}$} & \multicolumn{4}{|c|}{ Goldstein's $\delta \mu^{2}$} & \multicolumn{4}{|c|}{ Nei's uD } \\
\hline & Intercept & ${ }^{C}$ Slope ${ }^{C}$ & $\mathbf{r}^{2}$ & $\mathbf{P}$ & Intercept $^{\mathrm{C}}$ & Slope $^{\mathrm{C}}$ & $\mathbf{r}^{2}$ & $\mathbf{P}$ \\
\hline All & 60.23 & 21.26 & $7.022 \mathrm{E}-03$ & 0.136 & 2.44 & 0.79 & 0.033 & $0.004 *$ \\
\hline 3 & 57.68 & 20.11 & 0.023 & 0.199 & 3.04 & 0.97 & 0.116 & $0.012 *$ \\
\hline 5 & 64.35 & 23.88 & 0.016 & 0.249 & 3.19 & 1.05 & 0.166 & $0.004 *$ \\
\hline 7 & 75.17 & 27.80 & 0.081 & 0.097 & 3.14 & 1.04 & 0.163 & $0.014^{*}$ \\
\hline 8 & 69.37 & 26.41 & 0.033 & 0.251 & 3.50 & 1.21 & 0.079 & 0.108 \\
\hline 9 & 67.04 & 25.29 & 0.027 & 0.230 & 3.29 & 1.15 & 0.052 & 0.159 \\
\hline 10 & 70.56 & 26.96 & 0.026 & 0.261 & 3.35 & 1.19 & 0.040 & 0.247 \\
\hline 11 & 72.71 & 27.56 & 0.030 & 0.274 & 3.41 & 1.18 & 0.111 & 0.075 \\
\hline 12 & 75.33 & 28.12 & 0.037 & 0.216 & 3.46 & 1.15 & 0.161 & 0.050 \\
\hline 17 & 74.82 & 28.64 & 0.025 & 0.305 & 3.52 & 1.24 & 0.124 & 0.124 \\
\hline 19 & 76.82 & 28.94 & 0.052 & 0.218 & 3.55 & 1.19 & 0.189 & 0.057 \\
\hline 20 & 73.49 & 27.90 & 0.038 & 0.242 & 3.68 & 1.30 & 0.136 & 0.149 \\
\hline 21 & 63.62 & 22.05 & 0.026 & 0.322 & 3.05 & 0.97 & 0.199 & 0.076 \\
\hline 22 & 64.86 & 22.52 & 0.084 & 0.177 & 3.09 & 0.98 & 0.218 & 0.083 \\
\hline 23 & 81.59 & 28.03 & 0.017 & 0.319 & 3.06 & 0.96 & 0.235 & 0.062 \\
\hline 27 & -29.57 & -19.02 & $4.27 \mathrm{E}-04$ & 0.563 & 2.69 & 0.78 & 0.188 & 0.072 \\
\hline 28 & -38.35 & -23.91 & $7.70 \mathrm{E}-04$ & 0.528 & 3.10 & 0.97 & 0.242 & 0.054 \\
\hline
\end{tabular}

${ }^{\text {A }}$ Mantel tests were conducted independently using two different genetic distances $-\delta \mu^{2}$ (Goldstein et al., 1995) and Nei's unbiased standard genetic distance (Nei, 1978)

В The unburnt sampling plot analysed together with the recently burnt plots (to ignore distances between unburnt plots)

${ }^{\mathrm{C}}$ Intercepts and slopes were calculated through reduced major axis (RMA) regression analysis $* \mathrm{P}<0.05$ after 1000 randomizations 


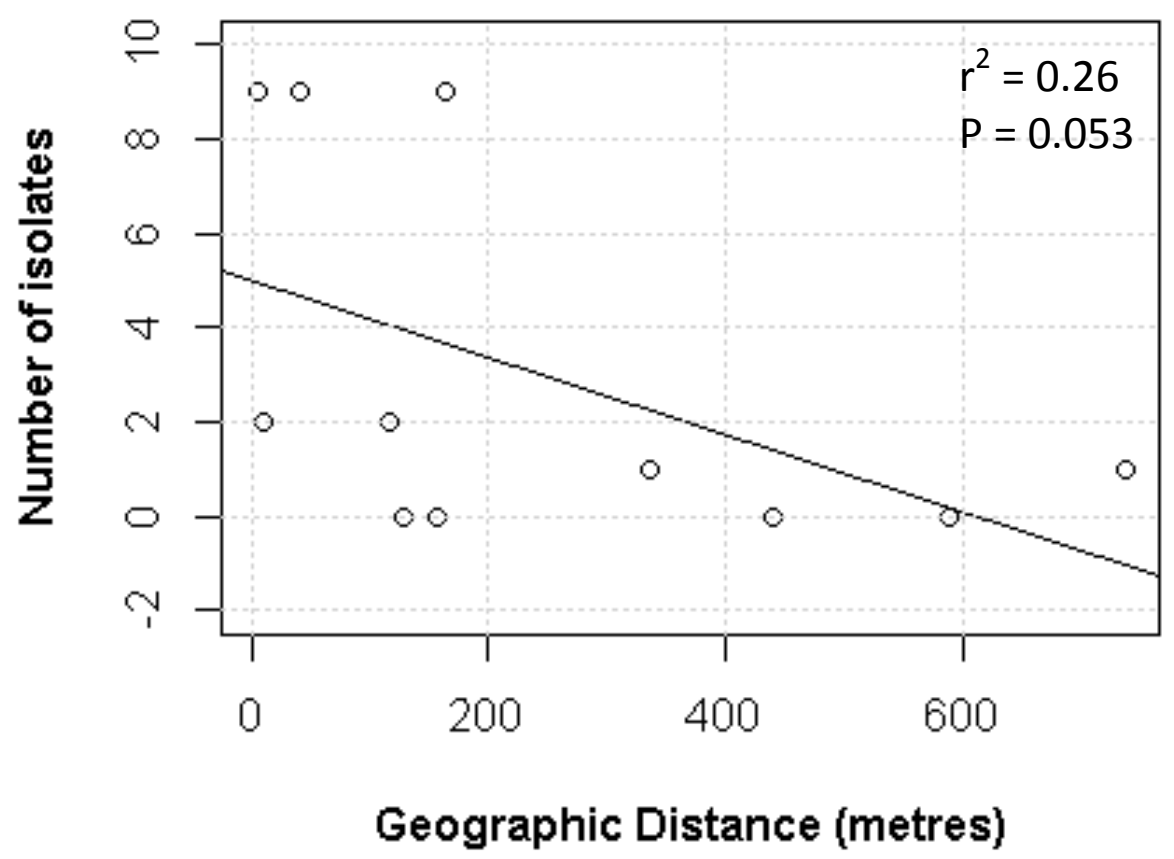

Figure S1 - Correlation between the number of Knoxdaviesia proteae isolates obtained from each sampling plot in the recently burnt areas and the geographic distance to the nearest unburnt sampling plot. Similar results were obtained when using the logarithmic geographic distance. 


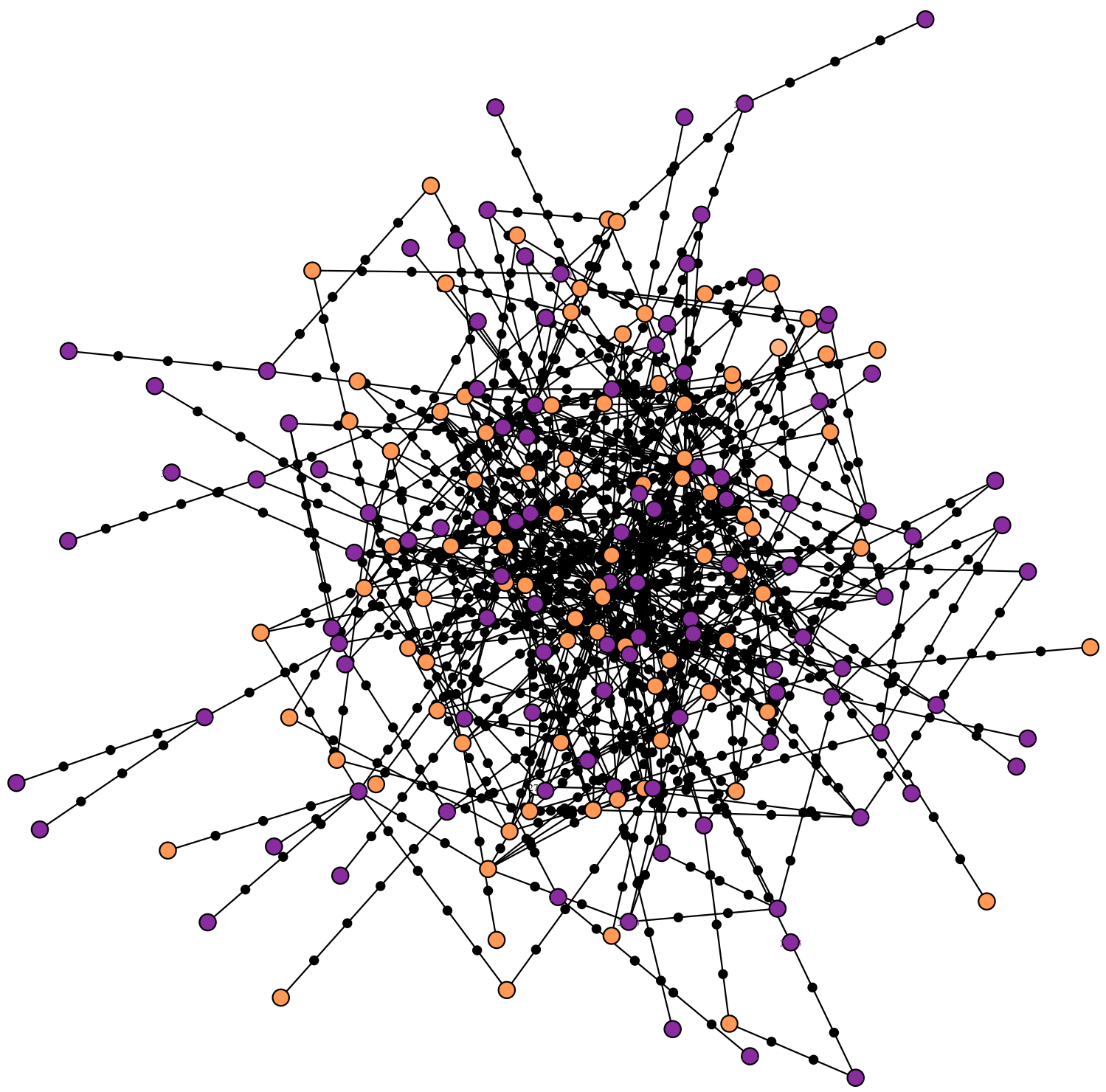

Figure S2 - Minimum Spanning Network (MSN) depicting the relationships between the 196 unique genotypes in the Gouritz (orange) and Franschoek (purple) populations. Black dots indicate missing genotypes. 
Table S3 - Number of Knoxdaviesia proteae isolates obtained from the different sampling plots in Franschoek Mountain.

\begin{tabular}{ccccc}
\hline \multicolumn{2}{c}{ Unburnt } & & \multicolumn{2}{c}{ Burnt } \\
\cline { 1 - 2 } \cline { 5 - 5 } Plot & Isolates & & Plot & Isolates \\
1 & 0 & & 4 & 2 \\
2 & 0 & & 6 & 0 \\
3 & 3 & & 13 & 0 \\
5 & 7 & & 14 & 1 \\
7 & 2 & & 15 & 0 \\
8 & 4 & & 16 & 0 \\
9 & 10 & & 24 & 9 \\
10 & 7 & & 25 & 2 \\
11 & 5 & & 26 & 9 \\
12 & 1 & & 29 & 9 \\
17 & 6 & & 30 & 1 \\
18 & 0 & & \\
19 & 2 & & \\
20 & 5 & & \\
21 & 3 & & \\
22 & 4 & & \\
23 & 4 & & \\
27 & 7 & & \\
28 & 3 & & \\
Total & 73 & & \\
\hline
\end{tabular}


Table S4 - Results of the Mantel tests ${ }^{A}$ conducted between individual unburnt plots and recently burnt plots.

\begin{tabular}{|c|c|c|c|c|c|c|c|c|}
\hline \multirow[b]{2}{*}{$\begin{array}{c}\text { Unburnt } \\
\text { sampling plots }\end{array}$} & \multicolumn{4}{|c|}{ Goldstein's $\delta \mu^{2}$} & \multicolumn{4}{|c|}{ Nei's uD } \\
\hline & Intercept & ${ }^{C}$ Slope ${ }^{C}$ & $\mathbf{r}^{2}$ & $\mathbf{P}$ & Intercept $^{\mathrm{C}}$ & Slope $^{\mathrm{C}}$ & $\mathbf{r}^{2}$ & $\mathbf{P}$ \\
\hline All & 60.23 & 21.26 & $7.022 \mathrm{E}-03$ & 0.136 & 2.44 & 0.79 & 0.033 & $0.004 *$ \\
\hline 3 & 57.68 & 20.11 & 0.023 & 0.199 & 3.04 & 0.97 & 0.116 & $0.012 *$ \\
\hline 5 & 64.35 & 23.88 & 0.016 & 0.249 & 3.19 & 1.05 & 0.166 & $0.004 *$ \\
\hline 7 & 75.17 & 27.80 & 0.081 & 0.097 & 3.14 & 1.04 & 0.163 & $0.014^{*}$ \\
\hline 8 & 69.37 & 26.41 & 0.033 & 0.251 & 3.50 & 1.21 & 0.079 & 0.108 \\
\hline 9 & 67.04 & 25.29 & 0.027 & 0.230 & 3.29 & 1.15 & 0.052 & 0.159 \\
\hline 10 & 70.56 & 26.96 & 0.026 & 0.261 & 3.35 & 1.19 & 0.040 & 0.247 \\
\hline 11 & 72.71 & 27.56 & 0.030 & 0.274 & 3.41 & 1.18 & 0.111 & 0.075 \\
\hline 12 & 75.33 & 28.12 & 0.037 & 0.216 & 3.46 & 1.15 & 0.161 & 0.050 \\
\hline 17 & 74.82 & 28.64 & 0.025 & 0.305 & 3.52 & 1.24 & 0.124 & 0.124 \\
\hline 19 & 76.82 & 28.94 & 0.052 & 0.218 & 3.55 & 1.19 & 0.189 & 0.057 \\
\hline 20 & 73.49 & 27.90 & 0.038 & 0.242 & 3.68 & 1.30 & 0.136 & 0.149 \\
\hline 21 & 63.62 & 22.05 & 0.026 & 0.322 & 3.05 & 0.97 & 0.199 & 0.076 \\
\hline 22 & 64.86 & 22.52 & 0.084 & 0.177 & 3.09 & 0.98 & 0.218 & 0.083 \\
\hline 23 & 81.59 & 28.03 & 0.017 & 0.319 & 3.06 & 0.96 & 0.235 & 0.062 \\
\hline 27 & -29.57 & -19.02 & $4.27 \mathrm{E}-04$ & 0.563 & 2.69 & 0.78 & 0.188 & 0.072 \\
\hline 28 & -38.35 & -23.91 & $7.70 \mathrm{E}-04$ & 0.528 & 3.10 & 0.97 & 0.242 & 0.054 \\
\hline
\end{tabular}

${ }^{\text {A }}$ Mantel tests were conducted independently using two different genetic distances $-\delta \mu^{2}$ (Goldstein et al., 1995) and Nei's unbiased standard genetic distance (Nei, 1978)

В The unburnt sampling plot analysed together with the recently burnt plots (to ignore distances between unburnt plots)

${ }^{\mathrm{C}}$ Intercepts and slopes were calculated through reduced major axis (RMA) regression analysis $* \mathrm{P}<0.05$ after 1000 randomizations 


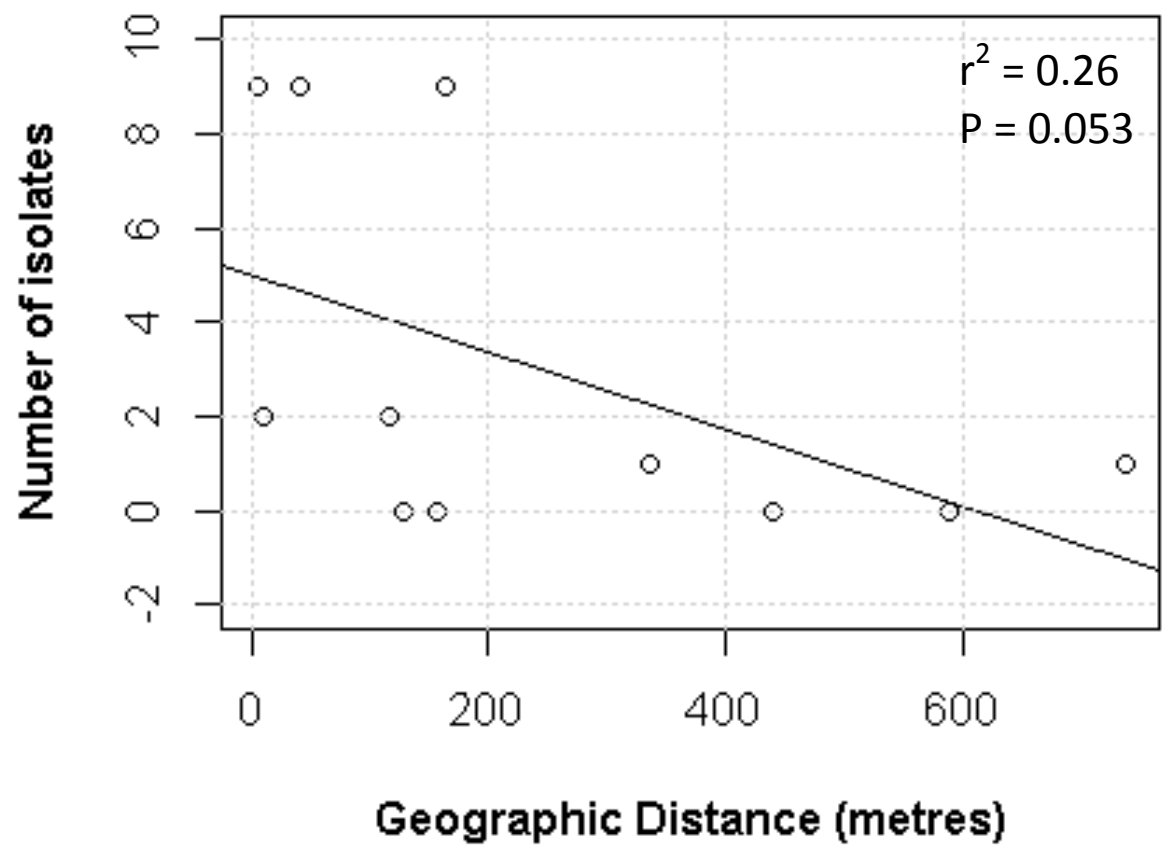

Figure S3 - Correlation between the number of Knoxdaviesia proteae isolates obtained from each sampling plot in the recently burnt areas and the geographic distance to the nearest unburnt sampling plot. Similar results were obtained when using the logarithmic geographic distance. 


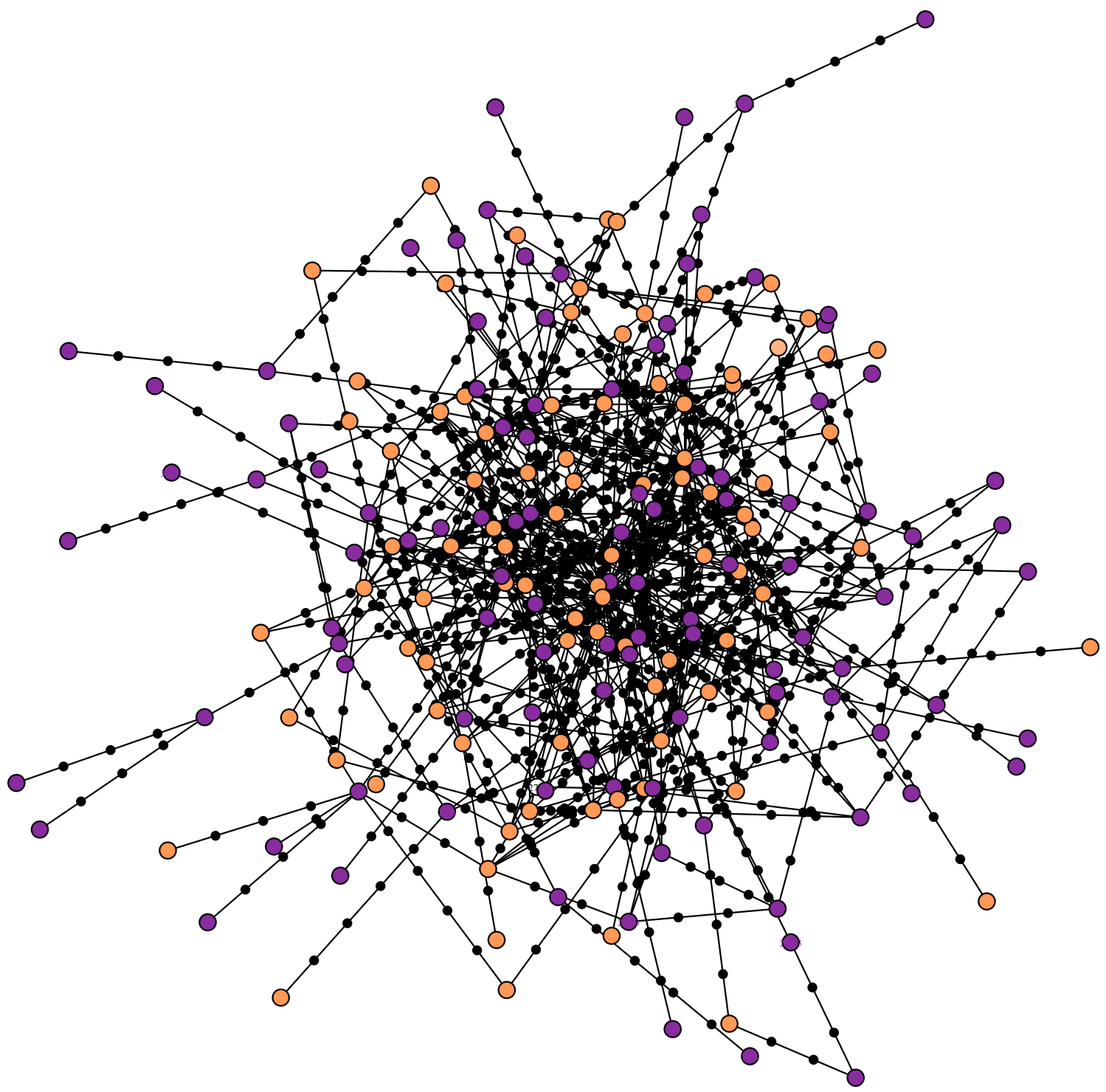

Figure S4 - Minimum Spanning Network (MSN) depicting the relationships between the 196 unique genotypes in the Gouritz (orange) and Franschoek (purple) populations. Black dots indicate missing genotypes. 